\title{
Frugivorous butterflies from the Atlantic Forest in Southern Brazil (Lepidoptera: Nymphalidae)
}

\author{
Sandra Mara Sabedot Bordin ${ }^{1 *} \mathbb{D}^{-}$, Marcelo Monteiro ${ }^{1}$, Valéria Wesner Ferreira ${ }^{1}$, Junir Antonio Lutinski ${ }^{2} \&$ \\ Everton Nei Lopes Rodrigues ${ }^{3}[$ \\ ${ }^{1}$ Universidade Comunitária da Região de Chapecó, Área de Ciências Exatas e Ambientais, Chapecó, SC, Brasil. \\ ${ }^{2}$ Universidade Comunitária da Região de Chapecó, Área de Ciências da Saúde, Chapecó, SC, Brasil. \\ ${ }^{3}$ Universidade do Vale do Rio dos Sinos, Programa de Pós-Graduação em Biologia, São Leopoldo, RS, Brasil. \\ *Corresponding author: Sandra Mara Sabedot Bordin,e-mail: sandrams@unochapeco.edu.br
}

SABEDOT BORDIN, S.M. MONTEIRO, M., FERREIRA, V.W., LUTINSKI, J.A., RODRIGUES, E.N.L. Frugivorous butterflies from the Atlantic Forest in Southern Brazil (Lepidoptera: Nymphalidae). Biota Neotropica. 19(4): e20180722. http://dx.doi.org/10.1590/1676-0611-BN-2018-0722

\begin{abstract}
This study aimed to present a list of the species of frugivorous butterflies occurring in Atlantic Forests, in the Conservation Units: National Forest of Chapecó (FLONA), Ecological Station of Mata Preta (ESEC) and State Park of Araucárias (PAEAR) and adjacent forest fragments, located in the western region of the state of Santa Catarina. Three samplings were conducted between December 2017 and March 2018, totaling 24 days of collection in each sampling area. Van Someren-Rydon traps were used to capture frugivorous butterflies. There were 4,231 frugivorous butterflies belonging to four subfamilies, 12 tribes and 49 species. In all, 37 species of frugivorous butterflies were sampled in FLONA and 29 in adjacent forest fragments. In ESEC, 29 species and 33 in adjacent forest fragments. In PAEAR, 33 species and 28 in adjacent forest fragments. Of the total species registered, 15 species are new records for the state of Santa Catarina and 11 are new records for the western region of the state. The most abundant species for FLONA were: Manataria hercyna (Hübner, 1821) and Hermeuptychia sp. In ESEC, were Hermeuptychia sp. and Yphthimoides ordinaria (Freitas, Kaminski \& Mielke, 2012). In PAEAR, greater abundance of Forsterinaria quantius (Godart, 1824) and Eryphanes reevesii (Doubleday, 1849) were verified. For the adjacent forest fragments to Conservation Units, there was a greater abundance of Hermeuptychia sp., Moneuptychia soter (Butler, 1877), Morpho epistrophus (Fabricius, 1796) e Forsterinaria quantius (Godart, 1824). Satyrinae presented higher richness $(\mathrm{S}=34)$ and abundance $(90.58 \%)$ in all areas sampled. The rarefaction and extrapolation curves for the Conservation Units and adjacent forest fragments showed a greater rise in the FLONA and PAEAR sampling units and their adjacent forest fragments. The estimated sampling coverage for Conservation Unit and forest fragments was above $97 \%$. The richness calculated through the Jackknife 1 estimator, for the FLONA and PAEAR samplings, presented a value of 50.75 and 37.09, respectively. The fauna of frugivorous butterflies from this region, first investigated in areas of Conservation Units, showed to be expressive and well represented in the Atlantic Forest Biome, indicating its potential as a refuge for biodiversity.
\end{abstract}

Keywords: conservation, diversity, ecology, forest fragmentation, species richness.

\section{Borboletas frugívoras da Mata Atlântica no Sul do Brasil (Lepidoptera: Nymphalidae)}

Resumo: O estudo teve como objetivo elaborar uma lista das espécies de borboletas frugívoras ocorrentes em florestas da Mata Atlântica, nas Unidades de Conservação: Floresta Nacional de Chapecó (FLONA), Estação Ecológica da Mata Preta (ESEC) e Parque Estadual das Araucárias (PAEAR) e fragmentos florestais adjacentes, localizados na Região Oeste de Santa Catarina. Foram realizadas três campanhas de coletas entre dezembro de 2017 e março de 2018, totalizando 24 dias de coletas em cada área amostral. Para a captura das borboletas frugívoras, foram utilizadas armadilhas Van Someren-Rydon. Foram registradas 4231 borboletas frugívoras pertencentes a quatro subfamílias, 12 tribos e 49 espécies. Foram amostradas 37 espécies de borboletas frugívoras na FLONA e 29 nos fragmentos florestais adjacentes. Na ESEC 29 espécies e 33 nos fragmentos florestais adjacentes. No PAEAR 33 espécies e 28 nos fragmentos florestais adjacentes. Do total de espécies registradas, 15 espécies de borboletas frugívoras são novos registros para o estado de Santa Catarina e 11 são novos registros para a região 
oeste do estado. As espécies mais abundantes para a FLONA foram: Manataria hercyna (Hübner, 1821) e Hermeuptychia sp. Na ESEC, foram Hermeuptychia sp. e Yphthimoides ordinaria (Freitas, Kaminski \& Mielke, 2012). No PAEAR verificou-se maior abundância das espécies Forsterinaria quantius (Godart, 1824) e Eryphanes reevesii (Doubleday, 1849). Para os fragmentos florestais adjacentes das Unidades de Conservação houve maior abundância das espécies: Hermeuptychia sp., Moneuptychia soter (Butler, 1877), Morpho epistrophus (Fabricius, 1796) e Forsterinaria quantius (Godart, 1824). Satyrinae apresentou maior riqueza ( $\mathrm{S}=34)$ e abundância $(90,58 \%)$ de borboletas frugívoras em todas as áreas amostradas. As curvas de rarefação e extrapolação, para as Unidades de Conservação e fragmentos florestais adjacentes mostraram uma maior ascendência nas unidades amostrais da FLONA e PAEAR e seus fragmentos florestais adjacentes. A cobertura estimada de amostragem para as borboletas frugívoras, para as Unidades de Conservação e fragmentos florestais, ficou acima de $97 \%$. A riqueza calculada através do estimador Jackknife 1, mostrou-se superior à riqueza observada, sendo que para as amostragens na FLONA e PAEAR, o estimador apresentou um valor de 50,75 e 37,09, respectivamente. A fauna de borboletas frugívoras da região, investigada pela primeira vez em áreas de Unidades de Conservação, mostrou-se bastante expressiva e bem representada no Bioma Mata Atlântica, indicando seu potencial como refúgio da biodiversidade.

Palavras-chave: conservação, diversidade, ecologia, fragmentação das florestas, riqueza de espécies.

\section{Introduction}

The Atlantic Forest is among the five main hotspots in the world (Morelatto \& Haddad 2000; Conservação Internacional 2013), considered one of the most important biomes worldwide due to its high biodiversity, high number of endemic species and deforestation rate (Myers et al. 2000). This biome covered approximately 13\% of the Brazilian territory (Cabral \& Cesco 2008), currently there are less than $12 \%$ of the original area, and the remaining areas are represented by more than 245,000 fragments, of which more than $95 \%$ are smaller than 250 hectares (Ribeiro et al. 2009).

The western region of the state of Santa Catarina was severely deforested throughout the 20th century, mainly by the economic development after European colonization, characterized by logging (Cabral \& Cesco 2008). As a consequence, large forest areas were gradually transformed into isolated fragments (Cerqueira et al. 2003, Cabral \& Cesco 2008). It is notable that over the centuries the process of forest fragmentation has intensified due to human activities on a continuous basis, generating effects such as the expansion of agricultural areas, the formation of urban areas and the construction of roads (Haddad et al. 2015).

Vibrans et al. (2013) present data from the Forest Floristic Survey of Santa Catarina highlighting that the state covers three different phytophysiognomies that make up the Atlantic Forest: Dense Ombrophilous Forest, Mixed Ombrophilous Forest and Decidual Seasonal Forest. The results show that the remaining native forest cover in the state is approximately $29 \%$. In the west of Santa Catarina, the forest cover of the Decidual Seasonal Forest is between 16 and 24\% of the Mixed Ombrophilous Forest (Vibrans et al. 2013).

Due to the rapidity with which anthropic impacts occur, selecting species or assemblages of species to establish conservation and monitoring priorities is critical (Kremen 1992). The composition, richness and abundance of Lepidoptera in the environments can be indicators of the degree of environmental preservation, being its study of fundamental importance in the understanding of the ecological interactions between the different environments (Duarte et al. 2012).

Considering this, the importance of studying butterflies came with the progress of research on biodiversity conservation, given the sensitivity to environmental changes, the fragmentation and reduction of natural areas (Freitas 2010). This is explained by the fact that butterflies are a large taxonomic group, faithful to their habitats, well known, quickly sampled and easily identified (Brown Jr. \& Freitas 2000).

Lepidoptera correspond to approximately 26,000 species described throughout Brazil (Brown \& Freitas 1999; Freitas \& Almeida 2012), of which more than 3,250 are butterflies (Freitas \& Marini-Filho 2011). In Brazil, strictly frugivorous butterflies are represented by four subfamilies of Nymphalidae: Satyrinae, Charaxinae, Biblidinae and some genera of Nymphalinae (Freitas et al. 2014). This guild comprises $50-75 \%$ of the Neotropical nymphalid fauna (Brown Jr. 2005), and because they are taxonomically and ecologically diverse in tropical environments, occur in all Brazilian biomes (Freitas et al. 2014).

Despite the diversity of habitats, there is little research concerning the order Lepidoptera in the state of Santa Catarina (Carneiro et al. 2008, Siewert et al. 2010a, Corso \& Hernandez 2012, Belaver et al. 2012, Orlandim et al. 2016). An extensive study was conducted by Ferro et al. (2012) with the moths Arctiinae and Siewert et al. (2010b) with Sphingidae. The knowledge of the fauna of butterflies in the western region of the state began with the contribution of the ancient naturalist Fritz Plaumann, who left a collection of approximately 4,000 butterflies, deposited at the Fritz Plaumann Entomological Museum in the municipality of Seara (Lubenow 2016). Some recent surveys of Lepidoptera (considering butterflies and/or moths), using entomological nets, were conducted in the western region in Santa Catarina, highlighting the research done by Silva et al. (2011), Favretto (2012), Schmith et al. (2012), Favretto et al. (2013), Favretto \& Santos (2014), Fanton \& Sabedot-Bordin (2014), Favretto et al. (2015), Silva \& Sabedot-Bordin (2015) and Colpani \& Sabedot-Bordin (2018).

Although some researchers have made collections of butterflies in the state of Santa Catarina using an entomological net, the data currently available in publications can still be considered scarce (Piovesan et al. 2014). The lack of publications on frugivorous butterflies in Conservation Units and adjacent forest fragments, in the western region in Santa Catarina, is evidenced through the bibliographic search, using a trap with attractive bait as a collection technique. With the purpose of contributing to the knowledge about the fauna of butterflies of Santa Catarina and in order to provide subsidies for the conservation of species, the study aimed to elaborate a list of frugivorous butterfly species of the western region of the state. 


\section{Material and Methods}

\section{Study areas}

The study was conducted in two Federal Conservation Units: National Forest of Chapecó (FLONA) (2706'24.8'S and 52 46'59.3”W) and Ecological Station of Mata Preta (ESEC) (26 $30^{\prime} 57.31^{\prime \prime} \mathrm{S}$ and 52 ${ }^{\circ}$ '59.69'W) and a State Conservation Unit: State Park of Araucárias (PAEAR) (26 27'08'S and 52 33'56”W). All Conservation Units are fully protected and are located in the western region of the state of Santa Catarina, southern Brazil (Figure 1). The Conservation Units are inserted in areas that during the last decades suffered from intense pressure of forest exploitation and agricultural expansion. Around the Conservation Units, there are monocultures such as soybean and corn, grown by the conventional method and often occurring the use of transgenics (Apremavi 2009). All Conservation Units are inserted in the Atlantic Forest Biome with forest phytophysiognomies classified as Mixed Ombrophilous Forest with different successional stages (Dick et al. 2013).

FLONA is located in the municipalities of Chapecó and Guatambú, was created in 1968 and has an area of 1,590 hectares. Samplings of frugivorous butterflies were performed in fragment I of FLONA with an area of 1,287.54 hectares, located in Guatambú (ICMBio 2013).
The ESEC of Mata Preta was established in 2005, has an area of 6,536 hectares and is located in the municipality of Abelardo Luz. Extensions of the ESEC of Mata Preta constitute private areas whose owners present legal proceedings in progress regarding the formation of the Conservation Unit (Apremavi 2009).

PAEAR was created in 2003 and covers an area of 612.5 hectares. PAEAR is located between the municipalities of São Domingos and Galvão. The creation of the park was a compensatory action established by the formation of the reservoir of the Quebra Queixo Hydroelectric Power Plant, located in the Chapecó River, in the municipalities of Ipuaçu and São Domingos (Fatma 2016).

The climate of the western region of the state of Santa Catarina is cfa, subtropical humid, with abundant rainfall well distributed throughout the year. The average annual temperature is lower than $18^{\circ} \mathrm{C}$ and with average temperatures ranging from $13^{\circ} \mathrm{C}$ and $25^{\circ} \mathrm{C}$ (Alvares et al. 2014).

\section{Sampling design}

In order to collect the frugivorous butterflies, five sampling units (five for FLONA and PAEAR, three for ESEC) were defined inside the Conservation Units (CU) and a single sampling unit in each of the adjacent forest fragments of each CU. Five adjacent forest

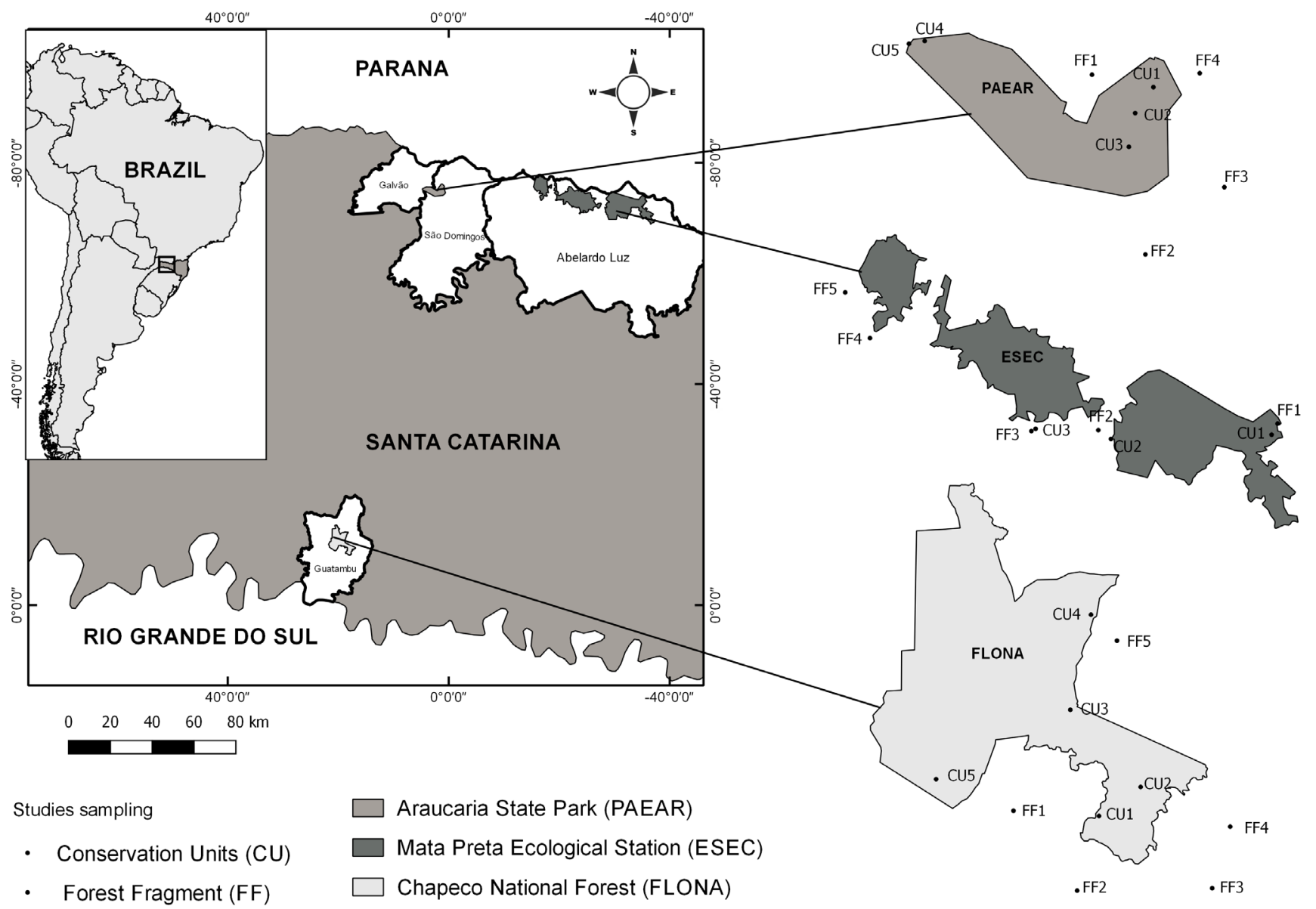

Figure 1. Map of the study areas and sample units for collections of frugivorous butterflies in the municipalities of Guatambú, Abelardo Luz and São Domingos, Santa Catarina, from December 2017 to March 2018. 
fragments were defined for FLONA and ESEC, and four for PAEAR (Figure 1). Adjacent forest fragments were different in size and had different distances from CU. Among the adjacent forest fragments there was a minimum distance of 250 meters (Santos et al. 2014). The sampling unit was formed by a linear transect. At the transect, the first trap was allocated at a distance of at least 50 meters from the edge (Uehara-Prado 2003). In each transect, there were a set of five traps for the capture of butterflies (Freitas et al. 2014), distanced from 30 to 50 meters (Santos et al. 2014) from each other, depending on the availability of places to hang them in the trees. The other transects of the sampling units with a minimum distance of 250 meters between them. A total of 135 traps were installed, 50 traps in FLONA/fragments $(25 / 25)$; 40 traps in ESEC/fragments $(15 / 25)$ and 45 in PAEAR/ fragments $(25 / 20)$.

Three samplings were conducted in each $\mathrm{CU}$ and respective adjacent forest fragments, from December 2017 to March 2018, totaling 24 days of collection. The traps were left active on the field for eight consecutive days, being inspected every 48 hours for removal of the captured frugivorous butterflies and bait replacement.

The procedure for the collection of frugivorous butterflies followed the protocol established by the National Lepidoptera Research and Conservation Network (RedeLep). Van Someren-Rydon traps were used to collect frugivorous butterflies. The traps were suspended in trees by ropes, at a height of approximately $1.5 \mathrm{~m}$ above the ground level (Uehara-Prado 2005). Each trap was supplied with a $50 \mathrm{~mL}$ plastic bottle containing an attractive bait. The bait used consisted of a mixture of sugarcane juice with well-ripe bananas at a proportion of $1 / 3$, which was prepared 48 hours before the beginning of the sampling, time required to occur to the fermentation (Uehara-Prado 2003).

The collected frugivorous butterflies were sacrificed by thoracic pressure at the base of the wings and conditioned in properly identified entomological envelopes (Almeida et al. 1998). The collected butterflies were taken to the Laboratory of Entomology of the Universidade Comunitária da Região de Chapecó (UNOCHAPECÓ) in Santa Catarina, Brazil, for freezer storage and subsequent identification of the species. Species identification was carried out through specialized literature of Canals (2003), Lamas (2004), Wahlberg (2009) and using online identification guide (http://butterfliesofamerica.com). Identification was also performed with the help of experts.

Specimens of each sampled species were deposited in the reference collection of the Laboratory of Entomology of the Universidade Comunitária da Região de Chapecó (UNOCHAPECÓ), Chapecó, Santa Catarina; in the Zoological Collection of the Universidade do Vale do Rio dos Sinos (MZ UNISINOS), São Leopoldo, Rio Grande do Sul, Brazil.

The collections were performed under the license issued by ICMBio (ICMBio/SISBio Collection License 60789-1).

To represent the composition, richness and abundance of frugivorous butterflies in CU and adjacent forest fragments, the species were listed according to their respective taxa of subfamilies, tribe and genus in addition to the presence in each environment.

Richness estimates and sample coverage were performed using the rarefaction and extrapolation curve based on the Chao 1 estimator with 40 nodes and 500 randomizations. The analysis was run with the iNEXT software (Chao et al. 2016).
Sampling adequacy was verified from the Jackknife 1 species richness estimator for all sampled areas using the EstimateS 9.1 software (Colwell 2013), as suggested by Toti et al. (2000). We used EstimateS with 500 randomizations.

To illustrate butterflies species composition comparisons two ordenations were plotted (Non-metric MultiDimensional Scaling nMDS) using a qualitative similarity index (Simpson). Qualitative analysis was performed using a species presence-absence matrix, using the Simpson index to build a dissimilarity matrix among sample units. To test for statistical differences among butterfly assemblage composition for the above similarity indexes, we applied two one-way ANOSIM (Analysis of Similarities) with Bonferroni correction, one for each factor. We also performed an analysis of similarity percentage (SIMPER) (Clarke \& Warwick 1994), based on Bray-Curtis distance, in order to identify those taxa responsible for observed differences in species composition among forest classes, also quantifying their relative contribution for such differences. Composition analyses were developed using PASt (Paleontological Statistics 2.17c, Hammer \& Harper 2009).

\section{Results}

There were 4,231 frugivorous butterflies belonging to four subfamilies, 12 tribes and 49 species (Table 1). In total, 49 species of frugivorous butterflies (2,418 individuals) were sampled in FLONA $(\mathrm{N}=670, \mathrm{~S}=37)$ and adjacent forest fragments $(\mathrm{N}=1,748, \mathrm{~S}=29) ; 37$ species (1,234 individuals) in ESEC $(\mathrm{N}=547, \mathrm{~S}=29)$ and adjacent forest fragments $(\mathrm{N}=687, \mathrm{~S}=33)$ and 35 species (579 individuals) in PAEAR $(\mathrm{N}=368, \mathrm{~S}=33)$ and adjacent forest fragments $(\mathrm{N}=211, \mathrm{~S}=28)$ (Table 1).

Of the total richness in FLONA and adjacent forest fragments, 25 species occurred in all sampled areas. In all, 12 species were sampled exclusively in the areas of $\mathrm{CU}$ and four in the adjacent forest fragments. In ESEC, 25 species were common to the areas sampled, four species were sampled exclusively in the areas of $\mathrm{CU}$ and eight occurred exclusively in the adjacent forest fragments. In turn, in PAEAR, 26 species were common to the sampled areas, another seven species were sampled exclusively in the CU areas and two occurred in the adjacent forest fragments (Table 1).

From the total of species, 15 species of frugivorous butterflies are new records for the state of Santa Catarina, namely 12 Satyrinae, two Biblidinae and one Charaxinae (Table 1). New species records for the state: Zaretis strigosus (Gmelin, 1790), Cissia eous (Butler, 1867), Moneuptychia soter (Butler, 1877) recorded in all sampled areas. Forsterinaria necys (Godart, 1824) was not recorded in the adjacent forest fragments of FLONA. Carminda paeon (Godart, 1804) was not sampled in PAEAR and adjacent forest fragments. Callicore hydaspes (Drury, 1782) was recorded only in FLONA and adjacent forest fragments; Paryphthimoides poltys (Prittwitz, 1865) was not sampled in ESEC, PAEAR and adjacent forest fragments. Eunica tatila (HerrichScäffer, 1855) and Splendeuptychia libitina (Butler, 1870), singleton species, occurring only in FLONA. Catoblepia amphirhoe (Hübner, 1825) was recorded in FLONA and adjacent forest fragments of PAEAR (doubleton) and Pseudodebis euptychidia (Butler, 1868) was sampled in FLONA, PAEAR and adjacent forest fragments. Splendeuptychia ambra (Weymer, 1911) registered in PAEAR. Taygetis laches (Fabricius, 1793) was not sampled in the adjacent forest fragments of PAEAR, FLONA 
Table 1. List of species of frugivorous butterflies sampled with Van Someren-Rydon traps recorded in Conservation Units and adjacent forest fragments, western region of the state of Santa Catarina, Brazil, between December 2017 and March 2018. (ES) ESEC; (F) FLONE; (P) PAEAR; (T) Total butterflies in Conservation Units; (FES) ESEC Fragments; (FF) FLONA Fragments; (FP) PAEAR Fragments; (FT) Total butterflies in forest fragments; *New records for Santa Catarina; **New records for the western region of state of Santa Catarina.

\begin{tabular}{|c|c|c|c|c|c|c|c|c|}
\hline \multirow[b]{2}{*}{ TAXON } & \multicolumn{4}{|c|}{ CONSERVATION UNITS } & \multicolumn{4}{|c|}{ FOREST FRAGMENTS } \\
\hline & ES & $\mathbf{F}$ & $\mathbf{P}$ & $\mathbf{T}$ & FES & FF & FP & FT \\
\hline \multicolumn{9}{|l|}{ Charaxinae $(S=5)$} \\
\hline \multicolumn{9}{|l|}{ Preponini $(S=2)$} \\
\hline Archaeoprepona chalciope (Hübner, 1823) & - & 1 & 8 & 9 & 1 & - & 2 & 3 \\
\hline Archaeoprepona demophon (Hübner, 1814)** & 2 & 1 & 2 & 5 & 3 & - & 2 & 5 \\
\hline \multicolumn{9}{|l|}{ Anaeini $(S=3)$} \\
\hline Memphis moruus stheno (Prittwitz, 1865) & - & 6 & 12 & 18 & 7 & 26 & 10 & 43 \\
\hline Zaretis strigosus (Gmelin, 1790)* & 2 & 4 & 2 & 8 & 6 & 11 & 1 & 18 \\
\hline \multicolumn{9}{|l|}{ Biblidinae $(S=10)$} \\
\hline \multicolumn{9}{|l|}{ Biblidini $(S=1)$} \\
\hline \multicolumn{9}{|l|}{ Epicaliini $(S=3)$} \\
\hline Cybdelis phaesyla (Hübner, 1825) & 1 & 1 & - & 2 & 3 & 1 & - & 4 \\
\hline Eunica eburnea Fruhstorfer, 1907 & 3 & - & - & 3 & - & - & - & - \\
\hline Eunica tatila (Herrich-Schäffer, 1855)* & - & 1 & - & 1 & - & - & - & - \\
\hline \multicolumn{9}{|l|}{ Epiphilini (S=3) } \\
\hline Epiphile hubneri (Hewitson, 1952) & 11 & 2 & 1 & 14 & 12 & 3 & - & 15 \\
\hline Epiphile orea orea (Hübner, 1823) & 13 & 18 & 1 & 32 & 9 & - & 2 & 11 \\
\hline Temenis laothoe Cramer, 1777 & - & 1 & - & 1 & - & 6 & - & 6 \\
\hline Blepolenis catharinae (Stichel, 1902)** & - & - & - & - & 4 & - & - & 4 \\
\hline Caligo illioneus (Cramer, 1776) & - & 4 & - & 4 & - & 2 & - & 2 \\
\hline Caligo martia (Godart, 1824) & - & - & 1 & 1 & - & - & 1 & 1 \\
\hline Catoblepia amphirhoe (Hübner, 1825)* & - & 1 & - & 1 & - & - & 1 & 1 \\
\hline Eryphanis reevesii (Doubleday, 1849) & 65 & 29 & 56 & 150 & 20 & 7 & 9 & 36 \\
\hline Opoptera sulcius (Staudinger, 1887)** & 18 & - & 15 & 33 & 11 & - & 10 & 21 \\
\hline Opsiphanes invirae (Hübner, 1808) & 2 & 2 & 1 & 5 & 1 & - & 1 & 2 \\
\hline \multicolumn{9}{|l|}{ Satyrini $(S=21)$} \\
\hline Carminda paeon (Godart, 1804)* & 7 & 1 & - & 8 & 12 & 3 & - & 15 \\
\hline Cissia eous (Butler, 1867)* & 10 & 8 & 18 & 36 & 32 & 139 & 11 & 182 \\
\hline Cissia phronius (Godart, 1824) & 1 & 6 & 7 & 14 & 6 & 64 & 8 & 78 \\
\hline Euptychoides castrensis (Schaus, 1902)** & 19 & 13 & 1 & 33 & 15 & 72 & - & 87 \\
\hline Forsterinaria necys (Godart, 1824)* & 6 & 2 & 20 & 28 & 1 & - & 2 & 3 \\
\hline Forsterinaria quantius (Godart, 1824) & 21 & 43 & 65 & 129 & 9 & 6 & 23 & 38 \\
\hline Godartiana muscosa (Butler, 1870)** & 1 & - & 6 & 7 & 5 & 1 & 2 & 8 \\
\hline
\end{tabular}


Continuation Table 1.

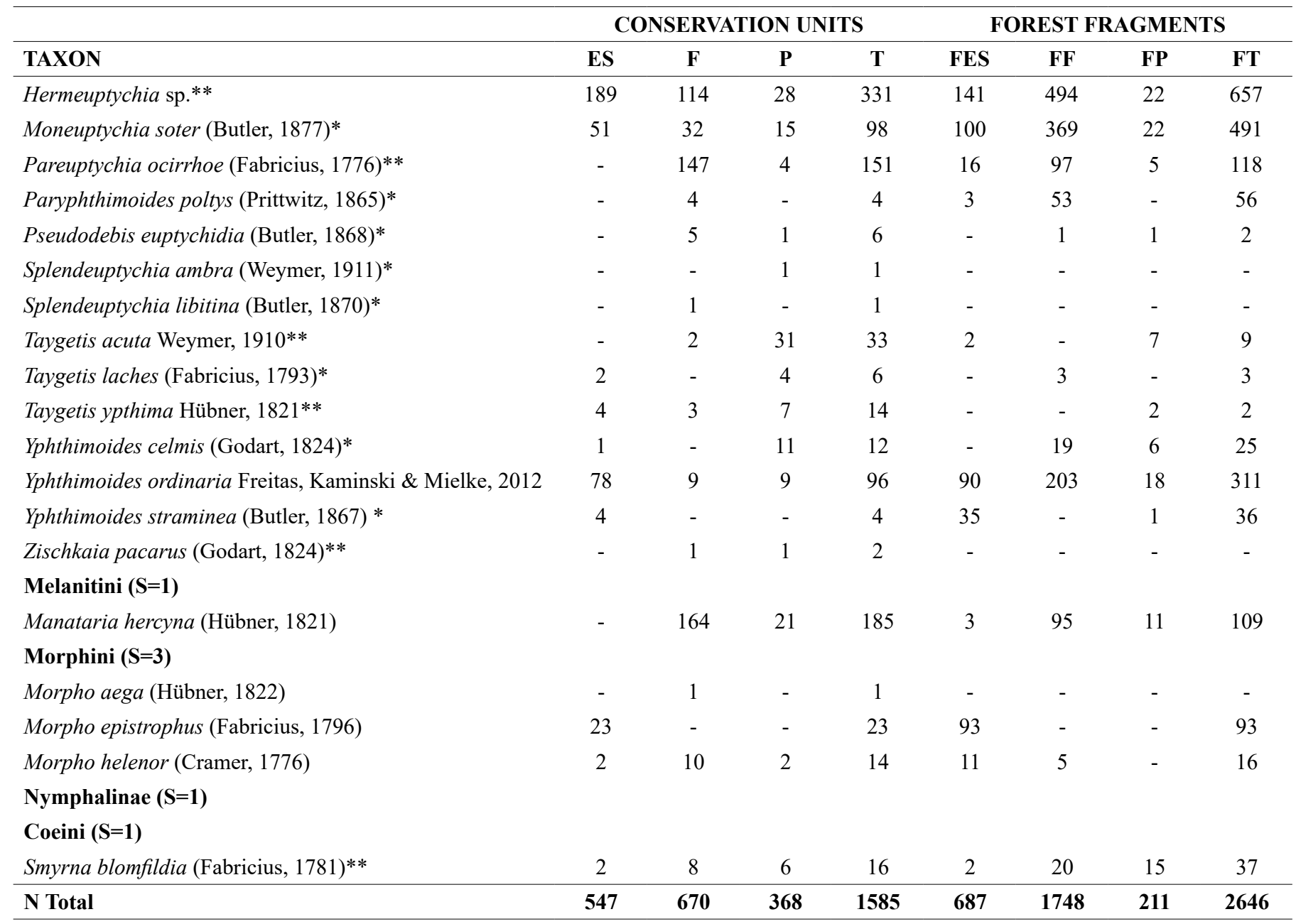

and their adjacent forest fragments. Yphthimoides straminea (Butler, 1867 ) in the ESEC, FLONA and adjacent forest fragments of PAEAR. Yphthimoides celmis (Godart, 1824) did not occur in the FLONA and adjacent forest fragments of the ESEC (Table 1).

The study added 11 new records of frugivorous butterflies to the western region of the state of Santa Catarina, with eight Satyrinae, one Charaxinae and Nymphalinae (Table 1). Hermeuptychia sp., Pareuptychia ocirrhoe (Fabricius, 1776) and Smyrna blomfildia (Fabricius, 1781) recorded in all areas sampled. Archaeoprepona demophon (Hübner, 1814) recorded in all areas sampled with the exception of the adjacent forest fragments of FLONA. Blepolenis catharinae (Stichel, 1902) sampled in ESEC. Opoptera sulcius (Staudinger, 1887) was not recorded in FLONA and adjacent forest fragments. Euptychoides castrensis (Schaus, 1902) did not occur in the adjacent forest fragments of PAEAR. Godartiana muscosa (Butler, 1870) was not registered in FLONA. Taygetis acuta (Weymer, 1910) was not recorded in ESEC and adjacent forest fragments of FLONA. Taygetis yptima (Hübner, 1821) was not recorded in the adjacent forest fragments of ESEC and FLONA and Zischkaia pacarus (Godart, 1824) was only sampled in FLONA (singleton) (Table 1).

The most abundant species in FLONA were Manataria hercyna (Hübner, 1821) with 164 individuals (24.48\%), P. ocirrhoe (Fabricius, 1776) with 147 (21.94\%) and Hermeuptychia sp. with 114 (17.01\%)
(Table 1, Figure 2a). On the other hand, in the CU, 27 species of frugivorous butterflies totaled less than 10 individuals, being generally restricted to a single area sampled. Among the total fauna of frugivorous butterflies in the CU, 12 singletons were recorded: $A$. demophon (Hübner, 1814), Archaeoprepona chalciope (Hübner, 1814), C. hydaspes (Drury, 1782), C. paeon (Godart, 1804), C. amphirhoe (Hübner, 1825), Cybdelis phaesyla (Hübner, 1825), E. tatila (Herrich-Schäffer, 1855), Hamadryas epinome (Felder \& Felder, 1867), Morpho aega (Hübner, 1822), S. libitina (Butler, 1870), Temenis laothoe (Cramer, 1777) and Z. pacarus (Godart, 1824) and five doubletons: Epiphile hubneri (Hewitson, 1952), F. necys (Godart, 1824), Memphis acidalia victoria (H. Druce, 1877), Opsiphanes invirae (Hübner, 1808) and T. acuta (Weymer, 1911) (Table 1, Table 2).

In the adjacent forest fragments of FLONA, it was verified that the most abundant species were Hermeuptychia sp. with 494 individuals (28.26\%), M. soter (Butler 1877) with 369 (21.11\%) and Y. ordinaria (Freitas, Kaminski \& Mielke 2012) with 203 (11.61\%) (Table 1, Figure 2a). In these forest fragments, 15 species of frugivorous butterflies numbered less than 10 individuals and four singletons were recorded: C. phaesyla (Hübner, 1825), G. muscosa (Butler, 1870), Hamadryas amphinome (Linnaeus, 1767) and P. euptychidia (Butler, 1868) and two doubletons: C. hydaspes (Drury, 1782) and Caligo illioneus (Cramer, 1776) (Table 1, Table 2). 

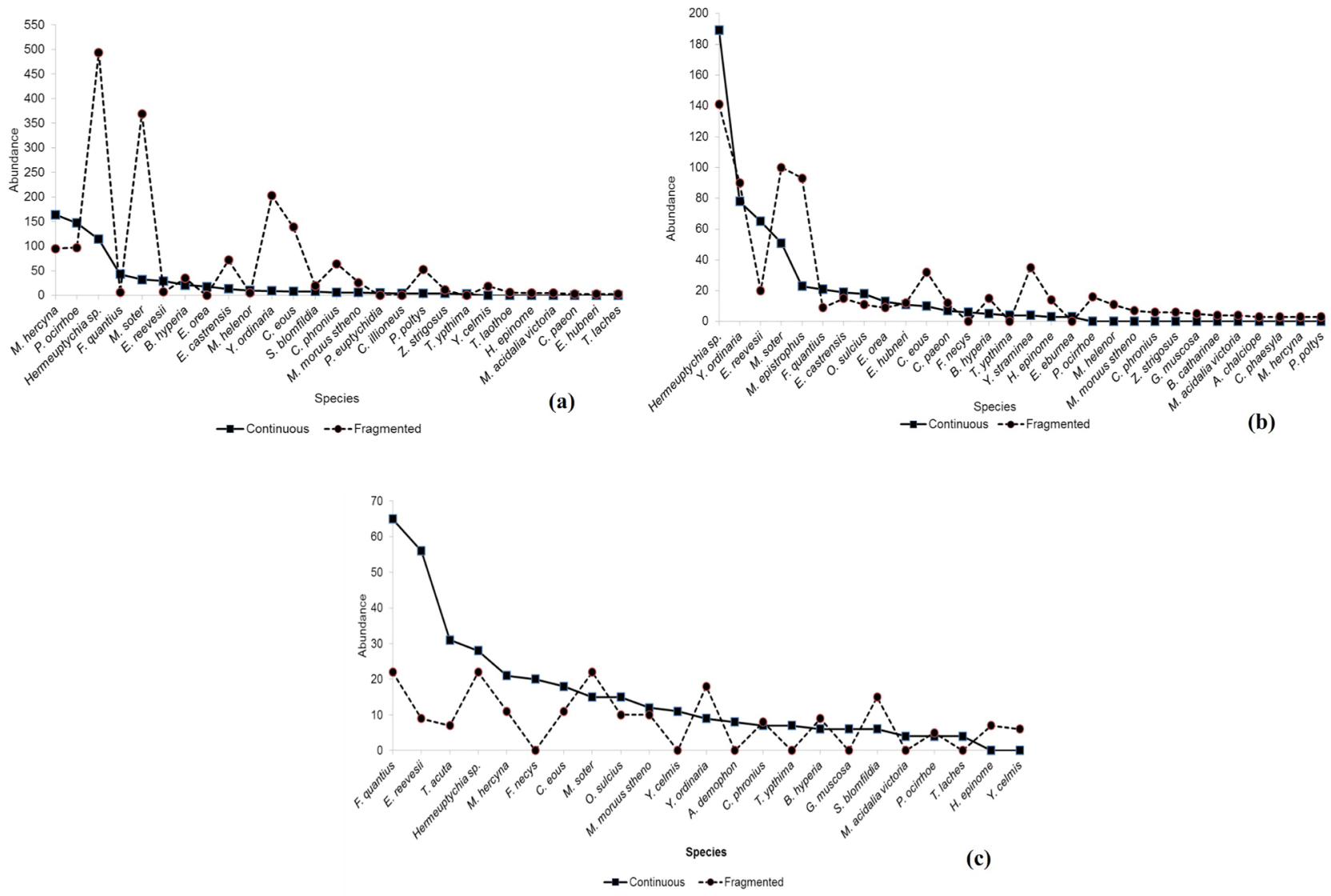

Figure 2. Distribution of abundance of frugivorous butterflies species sampled with Van Someren-Rydon traps in Conservation Units and adjacent forest fragments, from December 2017 to March 2018, in the western region of Santa Catarina, Brazil. 2a = FLONA; 2b = ESEC; 2c = PAEAR.

Table 2. Species richness, abundance and Jackknife 1 species richness estimator for the guild of frugivorous butterflies sampled with Van Someren-Rydon traps, recorded in Conservation Units (CU) and adjacent forest fragments (FF), in the western region of the state of Santa Catarina, between December 2017 and March 2018.

\begin{tabular}{lcccccc}
\hline Sampling areas & FLONA/CU & FLONA/FF & ESEC/CU & ESEC/FF & PAEAR/CU & PAEAR/FF \\
\hline Species richness & 37 & 29 & 29 & 33 & 33 & 28 \\
Abundance & 670 & 1748 & 547 & 5 & 687 & 368 \\
Singletons & 12 & 2 & 6 & 211 \\
Doubletons & 5 & $34.58 \pm 2.12$ & $36.36 \pm 2.43$ & $37.52 \pm 1.63$ & $43.08 \pm 2.12$ \\
Jackknife 1 & $50.75 \pm 4.09$ & & & 3 & 3 \\
\hline
\end{tabular}

In ESEC, Hermeuptychia sp. with 189 individuals (34.55\%), $Y$. ordinaria (Freitas, Kaminski \& Mielke, 2012) with 78 (14.26\%) and Eryphanes reevesii (Doubleday, 1849) with 65 (11.88\%) were the most abundant species (Table 1, Figure $2 \mathrm{~b}$ ). In the $\mathrm{CU}$, it was observed that 18 species of frugivorous butterflies totaled less than 10 individuals. Five species of singleton frugivorous butterflies were recorded: C. phronius (Godart, 1824), C. phaesyla (Hübner, 1825), G. muscosa (Butler, 1870), M. acidalia victoria (H. Druce, 1877) and Yphthimoides celmis (Godart, 1824), and six doubletons A. chalciope (Hübner, 1823), Morpho helenor (Cramer, 1776), O. invirae (Hübner, 1808), S. bomfildia (Fabricius, 1781), T. laches (Fabricius, 1793) and Z. strigosus (Gmelin, 1790) (Table 1, Table 2).

Hermeuptychia sp. with 141 individuals (20.52\%), M. soter (Butler, 1877 ) with 100 (14.55\%) and Morpho epistrophus (Fabricius, 1796) with $93(13.53 \%)$ presented greater abundance in the adjacent forest fragments of ESEC (Table 1, Figure 2b). In these forest fragments, there were 18 species of frugivorous butterflies with less than 10 species, four singletons: A. demophon (Hübner, 1814), Blepolenis bassus (Felder \& Felder, 1867), F. necys (Godart, 1824) and O. invirae (Hübner, 1808) and two doubletons: S. bomfildia (Fabricius, 1781) and T. acuta (Weymer, 1910) (Table 1, Table 2).

In PAEAR, there was a greater abundance of Forsterinaria quantius (Godart, 1824) with 65 individuals (17.66\%), E. reevesii (Doubleday, $1849)$ with $56(15.22 \%)$ and T. acuta Weymer, 1910 with 31 individuals $(8.42 \%)$ (Table 1, Figure 2c). It was observed that in the CU, 22 species of frugivorous butterflies with less than 10 individuals were sampled. Also, nine species of singleton frugivorous butterflies were found: Caligo martia (Godart, 1824), E. hubneri (Hewitson, 1952), Epiphile orea orea (Hübner, 1823), E. castrensis (Schaus, 1902), H. epinome (Felder \& Felder, 1867), O. invirae (Hübner, 1808), P. euptychidia (Butler, 1868), Splendeuptychia ambra (Weymer, 1911) and Z. pacarus (Godart, 1824) and three doubletons: A. chalciope (Hübner, 1823), M. helenor (Cramer, 1776) and Z. strigosus (Gmelin, 1790) (Table 1, Table 2). 
The most abundant species in the adjacent forest fragments of PAEAR were $F$. quantius (Godart, 1824) com 23 individuals (10.90\%), Hermeuptychia sp. and M. soter (Butler, 1877) with 22 (10.42\%) (Table 1, Figure 2c). For the forest fragments, 19 species of frugivorous butterflies with less than 10 species, six singletons: C. martia (Godart, 1824), C. amphirhoe (Hübner, 1825), O. invirae (Hübner, 1808), $P$. euptychidia (Butler, 1868), Yphthimoides straminea (Butler, 1867) e $Z$. strigosus (Gmelin, 1790) and six doubletons: A. demophon (Hübner, 1814), A. chalciope (Hübner, 1823), E. orea orea (Hübner, 1823), F. necys (Godart, 1824), G. muscosa (Butler, 1870) and T. ypthima (Hübner, 1821) (Table 1, Table 2).

The general distribution of abundance showed a pattern of high dominance (Table 1, Figure 2a, Figure 2b, Figure 2c). The five most abundant species make up more than $70 \%$ of the individuals sampled in FLONA (Figure 2a) and ESEC (Figure 2b). The five most abundant species in the adjacent forest fragments of FLONA also presented the same pattern of dominance (Figure 2a). The five most abundant species in the adjacent forest fragments of ESEC corresponded to more than $60 \%$ of the individuals sampled (Figure $2 \mathrm{~b}$ ). On the other hand, in PAEAR the five most abundant species totaled more than $50 \%$ of the individuals sampled and in the adjacent forest fragments of this $\mathrm{CU}, 46 \%$ dominance was observed in the five most abundant species (Figure 2c).

Satyrinae presented higher species richness (69.38\%) and abundance $(90.58 \%)$ of frugivorous butterflies in all sampled areas (Table 1, Table 3), followed by Biblidinae (5.19\%). Most of the captured frugivorous butterflies belong to the tribe Satyrini, being associated with all forest areas sampled (Table 1). It was found that in the adjacent forest fragments there was a higher percentage of Satyrinae when compared to $\mathrm{CU}$ (Table 3).

From the rarefaction and extrapolation curve, for the $\mathrm{CU}$ and respective forest fragments, based on the Chao 1 estimator (Figure 3), a total richness estimate was generated for the $\mathrm{CU}$ and adjacent forest fragments. The estimated sampling coverage for frugivorous butterflies in the CU and adjacent forest fragments was above $97 \%$. Figure 3 shows that the richness approached an asymptote, indicating a greater rise in the sampling areas of FLONA, and the PAEAR and adjacent forest fragments.

The parameters of richness and abundance of frugivorous butterflies showed variations, mainly between the areas in the $\mathrm{CU}$ and their respective forest fragments. The number of species of frugivorous butterflies varied between 28 (PAEAR/FF) and 37 (FLONA/CU). The abundance in turn ranged from 211 (PAEAR/FF) to 1748 (FLONA/ FF) butterflies (Table 2).

The Jackknife 1 richness estimator indicated that $72.9 \%$ of the frugivorous butterflies were sampled in FLONA and $83.7 \%$ for the adjacent forest fragments. In ESEC, the estimator indicated a sampling of $79.8 \%$ and $87.9 \%$ for the adjacent forest fragments. In PAEAR, the analysis indicated that $76.6 \%$ of the frugivorous butterflies were sampled and in the adjacent forest fragments, $75.5 \%$ (Table 2). The expected richness, calculated through the Jackknife 1 estimator, was higher than the richness obtained in the samplings, and for the FLONA and PAEAR samplings, the estimator presented a high value $(50.75$ and 37.09) (Table 2).

Qualitative ANOSIM analyses indicated different species composition among Conservations Units (ANOSIM: $\mathrm{R}=0.43, \mathrm{p}$ $=0.001$, Figure $4 \mathrm{a}$ ) and by forest fragments vs Conservation Units (ANOSIM: $\mathrm{R}=0.10, \mathrm{p}=0.001$, Figure $4 \mathrm{a}$ ). There is apparent founder effect in terms of species composition, since difference among sites (CU and FF) and between Conservation Units was found for Simpson index. Figure 4 illustrates a visual inspection of the nMDS scatterplots by species composition differences among Conservations Units (Figure 4a) and by forest fragments vs Conservation Units (Figure 4b).

The contribution of the most representative species in each environment to dissimilarity (SIMPER) between Conservation Units is presented in Table 4, and for different enviroments (CU vs FF) in Table 5. The most dominant species was Hermeuptychia sp. (overall contribution: 15,9\%, for Conservation Units, Table 4; overall contribution: $15,5 \%$, for CU vs FF, Table 5).

The species of greatest contribution to the dissimilarity among the CU belong to Satyrinae: Hermeuptychia sp. (15.9\%), M. hercyna (9.4\%) and $M$. soter ( $9 \%$ ) (Table 4$)$. These same species presented dissimilarity when analyzed between different environments, only $M$. soter $(9.27 \%)$ contributed more than M. hercyna (8.53\%) (Table 5).

\section{Discussion}

The total richness of frugivorous butterflies recorded in the present study was superior to what has been found for the state and western region of Santa Catarina [Carneiro et al. (2008) with 22; Corso \& Hernandez (2012), with 20 species; Schmidt et al. (2012) with two, Piovesan et al. (2014) with 43, Fanton \& Sabedot-Bordin (2014) with 14, Favretto et al. (2015), with 9, Silva \& Sabedot-Bordin (2015) with 16 and Colpani \& Sabedot-Bordin (2018) with 26]. The recent increase in the biodiversity studies on Lepidoptera is in the state of Santa Catarina highlighted, with surveys carried out in the municipalities of the Florianopolis, Joinvile and Joaçaba (Orlandim et al. 2016).

Although the aforementioned studies were carried out with different sampling efforts and prevailing the use of entomological nets, and in certain cases in restricted and smaller areas, such comparisons indicate that the environmental heterogeneity of the sampling areas favors the maintenance of the frugivorous butterfly diversity.

Table 3. Percentage of individuals of the subfamilies of frugivorous butterflies sampled with Van Someren-Rydon traps, recorded in Conservation Units and adjacent forest fragments in the western region of the state of Santa Catarina, Brazil, between December 2017 and March 2018. (F) FLONA; (ES) ESEC; (P) PAEAR; (T) Total butterflies in Conservation Units; (FF) FLONA Fragments; (FES) ESEC Fragments; (FP) PAEAR Fragments; (FT) Total butterflies in adjacent forest fragments.

\begin{tabular}{lcccccccc}
\hline Subfamilies & F & ES & P & T & FF & FES & FP & FT \\
\hline Satyrinae & 14.22 & 11.91 & 7.68 & 33.81 & 38.60 & 14.32 & 3.85 & 56.77 \\
Biblidinae & 1.09 & 0.85 & 0.21 & 2.15 & 1.25 & 1.37 & 0.42 \\
Charaxinae & 0.33 & 0.12 & 0.66 & 1.11 & 0.99 & 0.50 & 0.35 & 1.84 \\
Nymphalinae & 0.19 & 0.04 & 0.14 & 0.37 & 0.47 & 0.04 & 0.35 & 0.86 \\
\hline
\end{tabular}


Frugivorous butterflies in Southern Brazil
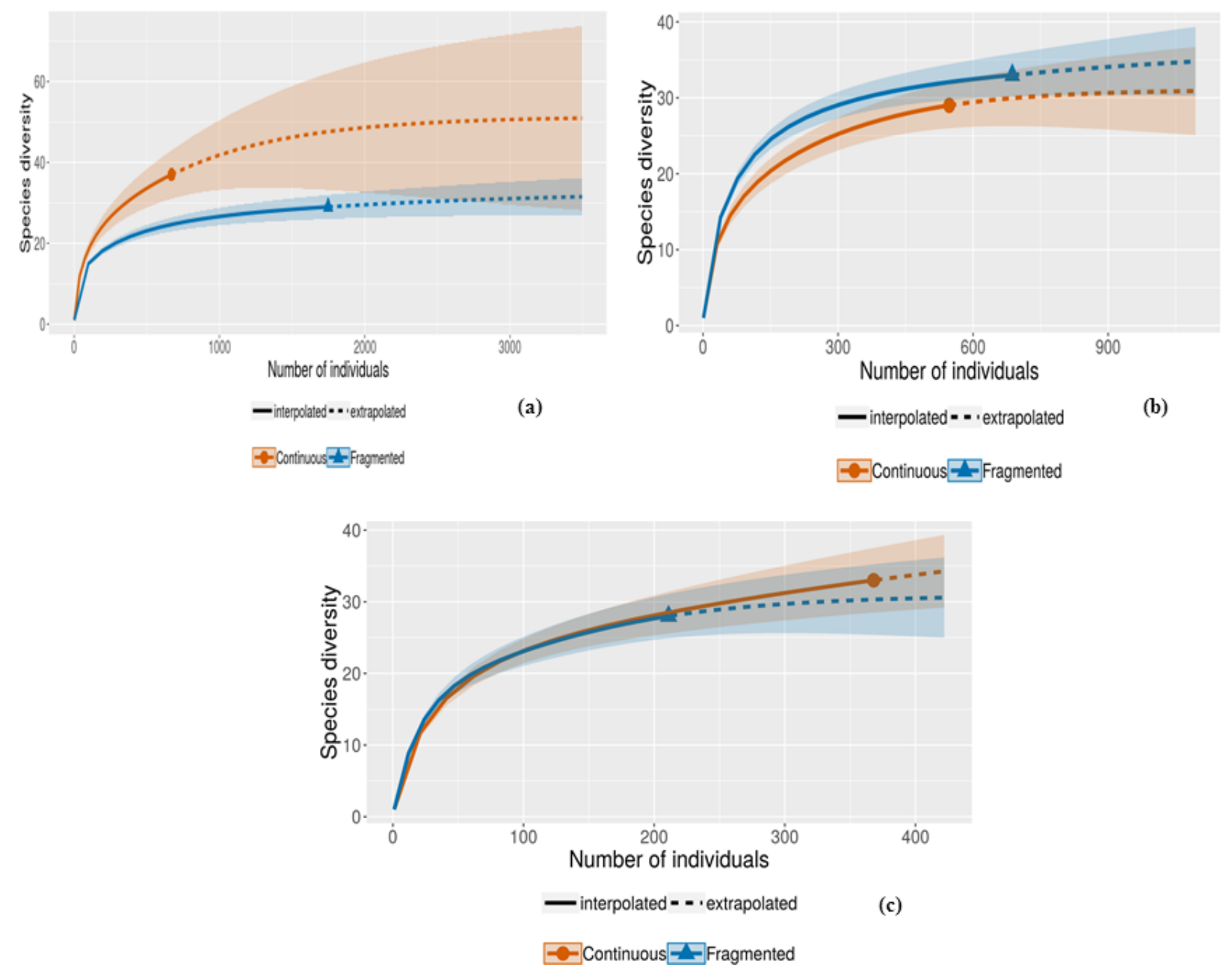

Figure 3. Richness estimates for rarefied and extrapolated sample for frugivorous butterflies sampled with Van Someren-Rydon traps in Conservation Units and adjacent forest fragments, western region of Santa Catarina, Brazil. $3 a=$ FLONA; $3 b=E S E C ; 3 c=$ PAEAR.

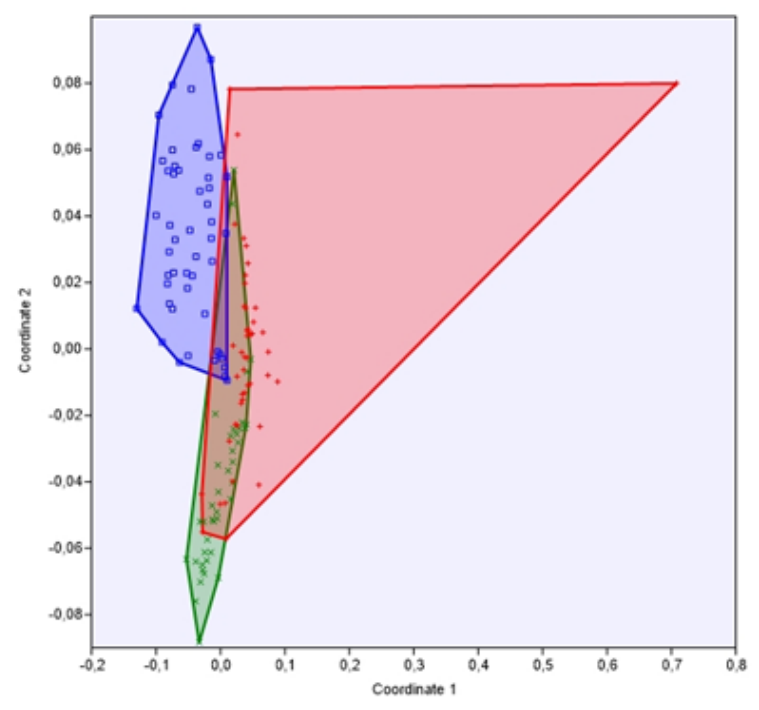

(a)

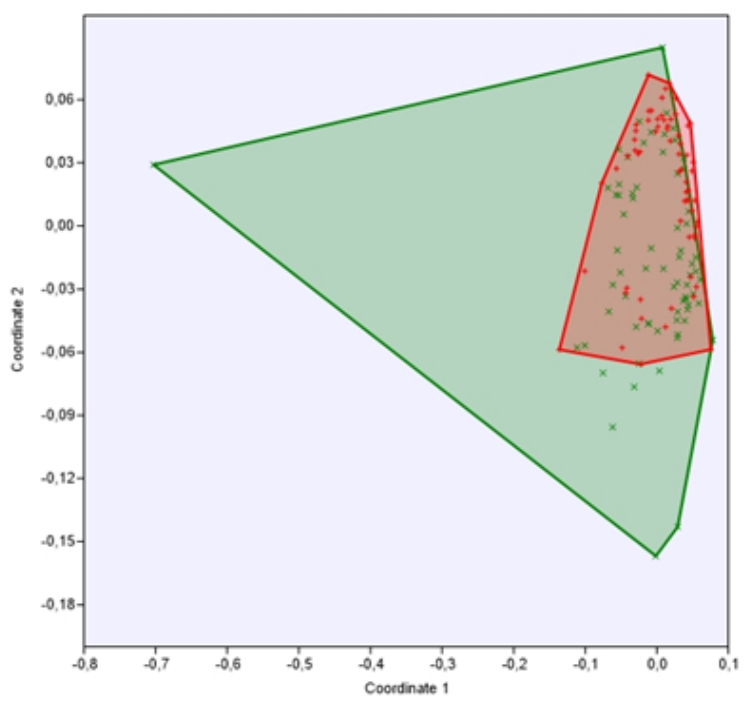

(b)

Figure 4. Ordination of butterflies faunal composition for Conservation Units (ESEC, FLONA, PAEAR), and for Conservation Units (CU) and adjacent forest fragments (FF) by Non-Metric MultiDimensional Scaling (nMDS), using qualitative similarity index in southern Brazil. (a) Conservation Units, ESEC, green; FLONA, blue; PAEAR, red. Simpson index. Stress = 0.439. (b) Environments, CU, red; and FF, green. Simpson index. Stress $=0.478$. 
Table 4. SIMPER analysis for ten butterflyes species contributing more to dissimilarities between the Conservation Units (ESEC, FLONA, PAEAR) in Brazil ( ${ }^{*}$ species percentage contribution to dissimilarity; ${ }^{*}$ cumulative dissimilarity among three $\mathrm{CU} ;{ }^{\dagger}$ average species abundance in each $\left.\mathrm{CU}\right)$.

\begin{tabular}{|c|c|c|c|c|c|}
\hline \multirow{2}{*}{ Species } & \multirow{2}{*}{ Contribution* } & \multirow{2}{*}{ Cumulative \% } & \multirow{2}{*}{$\begin{array}{c}\text { Mean abund }{ }^{\dagger}{ }^{\dagger} \\
\text { ESEC }\end{array}$} & \multirow{2}{*}{$\begin{array}{c}\text { Mean abund. }{ }^{\dagger} \\
\text { FLONA } \\
\end{array}$} & \multirow{2}{*}{$\begin{array}{c}\text { Mean abund }^{\dagger}{ }^{\dagger} \\
\text { PAEAR }\end{array}$} \\
\hline & & & & & \\
\hline Hermeuptychia sp. & 15.89 & 15.89 & 8.25 & 12.2 & 1.11 \\
\hline Moneuptychia soter & 9.07 & 34.35 & 3.77 & 8.02 & 0.82 \\
\hline Pareuptychia ocirrhoe & 8.82 & 43.17 & 0.4 & 4.88 & 0.2 \\
\hline Eryphanes reevesii & 5.82 & 56.56 & 2.13 & 0.72 & 1.44 \\
\hline Forsterinaria quantius & 5.30 & 61.86 & 0.75 & 0.98 & 1.96 \\
\hline Morpho epistrophus & 5.20 & 67.06 & 2.9 & 0 & 0 \\
\hline Cissia eous & 3.82 & 70.87 & 1.05 & 2.94 & 0.64 \\
\hline Biblis hyperia & 2.32 & 73.19 & 0.5 & 1.12 & 0.33 \\
\hline
\end{tabular}

Overall average dissimilarity: 83.2

Table 5. SIMPER analysis for ten butterflyes species contributing more to dissimilarities between florestal fragments (FF) and Conservation Unit (CU) in Brazil (*species percentage contribution to dissimilarity; ${ }^{*}$ cumulative dissimilarity among $\mathrm{FF}$ and $\mathrm{CU} ;{ }^{\dagger}$ average species abundance in each).

\begin{tabular}{lcccc}
\hline \multirow{2}{*}{ Species } & Contribution* & Cumulative \%\# & \multicolumn{2}{c}{ Mean abund. Mean abund. $^{\dagger}$} \\
\cline { 3 - 5 } Hermeuptychia sp. & 15.54 & 15.54 & FF & 5.39 \\
Moneuptychia soter & 9.27 & 24.81 & 7.01 & 1.51 \\
Manataria hercyna & 8.53 & 33.34 & 1.57 & 2.83 \\
Pareuptychia ocirrhoe & 7.69 & 41.03 & 1.69 & 2.32 \\
Yphthimoides ordinaria & 7.58 & 48.6 & 4.44 & 1.48 \\
Eryphanes reevesii & 6.65 & 55.26 & 0.51 & 2.31 \\
Forsterinaria quantius & 6.14 & 61.39 & 0.54 & 1.98 \\
Morpho epistrophus & 4.34 & 65.74 & 1.26 & 0.43 \\
Cissia eous & 4 & 69.73 & 2.6 & 0.55 \\
Biblis hyperia & 2.38 & 72.11 & 0.84 & 0.49 \\
\hline
\end{tabular}

Overall average dissimilarity: 84.06

In addition, surveys conducted using exclusively traps in fragments of Mixed Ombrophilous Forest in the state of Rio Grande do Sul, also disregarding differences in relation to sampling effort, identified a lower abundance of frugivorous butterflies compared to the present study [Graciotim \& Morais (2016) with 31 species; Pedrotti et al. (2011) with 30 and Giovenardi et al. (2008) with 32].

Satyrinae concentrated the greatest richness and abundance of species in the 27 sampling units, a representativeness that was also found in other studies with butterflies in the state (Corso \& Hernandez 2012, Carneiro et al. 2008, Schmidt et al. 2012, Piovesan et al. 2014, Fanton \& Sabedot-Bordin 2014, Favretto et al. 2015, Silva \& SabedotBordin 2015 and Colpani \& Sabedot-Bordin 2018). These results corroborate the observations of DeVries (1987) that the diversity of habitats in the neotropics would make the southern and southeastern regions of the Atlantic Forest of Brazil the largest in Satyrinae richness in the world, being considered the largest group within Nymphalidae (Lamas 2004).

The Neotropical Region is home to the greatest richness of satyrines of the world (D'abrera 1987). Satyrinae is a subfamily of wide diversity, biology and distribution, making up a third of all species of Nymphalidae
(Peña \& Wahlberg 2008). Its main host plants are monocotyledons (DeVries 1987; Peña \& Wahlberg 2008), abundant in clearings. The forest fragments sampled had trails and clearings, so it is believed that these spaces become conducive to the development and maintenance of this group, generating resources for both juveniles and adults.

Composing most of Satyrinae stands out the tribe Satyrini with more than 1,000 representatives among the almost 1,600 species of frugivorous butterflies in the Neotropical Region (Lamas 2004). In view of this representativeness, the high richness and abundance of Satyrini evidenced in the present study is not surprising. The high abundance of individuals obtained for the representatives of this tribe was associated with the areas that presented clearings. Bossart and Opuni-Frimpong (2009) point out that Satyrinae dynamics with grasses, which may become more numerous in environments with greater light penetration (for example, disturbed environments), can make this group an important biological indicator under the conditions of forest. According to Beccaloni et al. (2008), the host plants of Satyrini are composed mainly of grasses, host plants of caterpillars, thus the propagation of the tribe (Peña \& Wahlberg 2008). In this way, high population densities could be expected for this group in the areas sampled. 
An important Satyrinae species is M. hercyna (Hübner, 1821) because of its high abundance in FLONA (164 individuals). This species is considered rare in the northwest region of the state of Rio Grande do Sul (Biezanko 1960; Giovenardi et al. 2008) and Argentina (Nuñez-Bustos 2010). Manataria hercyna (Hübner, 1821) has crepuscular habitats, being found in dark and humid places (Nuñez-Bustos 2010) and is considered an indicator of an environment preserved in Atlantic Forest areas in southeastern Brazil (Brown Jr. $\&$ Freitas 2000). Other abundant Satyrinae in the sampled areas were Hermeuptychia sp., M. soter (Butler, 1877), F. quantius (Godart, 1824), Y. ordinaria (Freitas, Kaminski \& Mielke, 2012) with generalist habitats (Brown Jr. 1992) and being commonly found (Morais et al. 2007; Nuñez-Bustos 2010). Hermeuptychia sp. is among the ten most abundant species in the state of Rio Grande do Sul (Morais et al. 2007).

Butterflies Hermeuptychia are widely distributed from the Southeastern United States to northern Argentina and present a large number of individuals and almost ubiquitous in most butterfly lists to sites in the Neotropics (Seraphim et al. 2014). All eight species recognized within Hermeuptychia are small and brown, with very similar interspecific species (Lamas 2004). Seraphim et al. (2014) indicates that external morphologies and intraspecific variable ocelli patterns make taxonomic identification based on difficult morphology. Part of this biodiversity is hidden in the form of cryptic species, which can be defined as a group of morphologically similar species usually identified under a single name (Bickford et al. 2007).

Although the characteristics of the surroundings of all the areas sampled were equivalent, it was verified in the sampling period the presence of extensive agricultural areas, being able to influence the composition of the fauna and favor the high dominance of some species of frugivorous butterflies. For Marín et al. (2009), the intensification of agriculture can affect the quality of the matrix and the persistence of species inhabiting the fragments of forest inserted in it, favoring the dominance of some species. Considering that lepidopterans are affected mainly by the impacts of agricultural activities (Bonebracke et al. 2010), for butterflies in particular, the way the matrix influences the fauna can vary between different species or assemblages, so in general, the disturbances favor the generalist species and negatively affect specialists (Littlewood et al. 2011).

The fact that more than $60 \%$ of the fauna sampled is composed of some species of frugivorous butterflies more abundant, characterizes the community with a high degree of dominance. Fragmentation and modification of environments tends to alter the natural balance in the diversity of different groups. Not all species respond in the same way and there may be different responses up to the level of specimens (Samways 2005). Nevertheless, what tend to happen is the decline of specialist species and the increase of populations of generalist species. Species more abundant in forest remnants could be considered resistant to fragmentation dynamics, while species that show a remarkable decrease in abundance could presumably suffer the negative effects in relation to fragmentation (Uehara-Prado et al. 2005).

The rarefaction and extrapolation curves for the $\mathrm{CU}$ and their forest fragments provide reliable responses, since there was a large sampling effort in the study. The estimated sampling coverage, above $97 \%$, shows a good representation of the community of frugivorous butterflies in the region. For FLONA and PAEAR, it is observed that the richness approached an asymptote, indicating that a sample increase would contribute with few additional species. According to Brown Jr. \& Freitas (2000), in tropical environments, the curve rarely stabilizes.

The Jackknife 1 estimator shows that the richness of frugivorous butterflies in CU and forest fragments may be greater than the observed richness. Some studies show that richness of frugivorous species is higher in environments under stronger disturbances (Uehara-Prado et al. 2005), while others show that richness is lower in these environments and higher in more preserved environments (DeVries et al. 1997).

According to Bonebrake et al. (2010), butterfly communities are very variable between sites and between years, and are affected in the short term by differences in environmental/temporal conditions. Besides that, butterflies go out in search of host plants, food resources for adults, mating and overnight sites, reaching what is recognized as functional habitat (Marin et al. 2009). Therefore, it is important to establish relationships between the butterfly community and the vegetation structure, since both are closely related.

Studies emphasize how frugivorous butterflies are an excellent model for landscape characterization (Kremen 1992; Brown Jr. \& Freitas 2000, Uehara et al. 2007), which corroborates, with the results of our study, where we can detect differences between the composition between different $\mathrm{CU}$ and between different environments.

Uehara et al. (2007) showed differences in the composition of butterfly species and in the distribution along different habitats in landscapes. Other studies have revealed differences in composition in response to habitat structural variables and associations of species of butterflies and their subfamilies to habitats with varying degrees of disturbance (Kremen 1992, Brown Jr. \& Freitas 2000).

With the increasing reduction and modification of natural environments and the increasingly imminent threats to biodiversity, up-to-date studies on the ecology of species occupying a region, such as frugivorous butterflies, insects that can be very sensitive to environmental changes, are essential. Thus, the importance of surveys with a sampling methodology directed to the frugivorous butterflies is emphasized, allowing the adoption of actions contributing to the conservation of species.

The information generated through the present study contributes to the knowledge and characterization of the guild of frugivorous butterflies of the state. The fauna of frugivorous butterflies from the western region of the state of Santa Catarina, first investigated in areas of $\mathrm{CU}$, has shown to be quite expressive and well represented in the Atlantic Forest Biome, indicating it's potential as a refuge for biodiversity.

\section{Acknowledgements}

The authors thank the owners of the sampling areas for permission to access. To the management staff and employees of FLONA, ESEC and PAEAR. To the PhD André Victor Lucci Freitas (UNICAMP) and Fernando Maia Silva Dias (UFPR) for the identification of species of frugivorous butterflies. UNOCHAPECÓ for the support in the development of the research. To the biologist Thiago Bastiani and to the undergraduate students in Biological Sciences of UNOCHAPECÓ, in particular, Elizandra Carla da Silva, Juliana de Oliveira Dorneles, Ingridy Manila Colpani, Bruna da Silva, Bernard Dariva, Ricardo Bregalda, Larissa Gugel, Mauritius Fortes and Kelyta Paula dos Santos for their assistance in field collection. 


\section{Author Contributions}

Sandra Mara Sabedot Bordin: Contribution in data acquisition and identification of biological material; Contribution in the analysis and interpretation of data; Contribution in the preparation of the manuscript; Contribution in critical review, adding intellectual content.

Marcelo Monteiro: Contribution in data acquisition and identification of biological material.

Valéria Wesner Ferreira: Contribution in data acquisition and identification of biological material.

Junir Antonio Lutinski: Contribution in the analysis and interpretation of data; contribution in the critical review, adding intellectual content.

Everton Nei Lopes Rodrigues: Contribution in the analysis and interpretation of data; contribution in the critical review, adding intellectual content.

\section{Conflict of Interest}

The authors declare that they have no conflict of interest related to the publication of this manuscript.

\section{References}

ALMEIDA, L.M., RIBEIRO-COSTA, C.S. \& MARINONI, L. 1998. Manual de Coleta, Conservação, Montagem e Identificação de Insetos. Holos, São Paulo.

APREMAVI. 2009. Plano de Ação para a Conservação da Estação Ecológica da Mata Preta (ESEC). Curitiba. 33p.

ALVARES, C.A., STAPE, J.L., SENTELHAS, P.C., GONÇALVES, J.L.M. \& SPAROVEK, G. 2014. Köppen's climate classification map for Brazil. Meteorol. Z. 22(6):711-728.

BECCALONI, G.W., VILORIA, A.L., HALL, S.K. \& ROBINSON, G.S. 2008 Catalogue of The Hostplants of the Neotropical Butterflies. The Natural History Museum \& Instituto Venezolano de Investigaciones Cientificas, Zaragoza.

BELLAVER, J., ISERHARD, C.A., SANTOS, J.P., SILVA, A.K., TORRES, M., SIEWERT, R.R., MOSER, A. \& ROMANOWSKI, H.P. 2012. Borboletas (Lepidoptera: Papilionoidea e Hesperioidea) de Matas Paludosas e Matas de Restinga da Planície Costeira da Região Sul do Brasil. Biota Neotropica. 12(4): http://www.biotaneotropica.org.br/v12n4/en/abstract?inventory+ bn01812042012 (accessed: 9 December 2018).

BIEZANKO, C.M. 1960. Satyridae, Morphidae et Brassolidae da Zona Sueste do Rio Grande do Sul. Arquivos de Entomologia. Serie A, Edição do autor, Pelotas, p.1-13.

BICKFORD, D., LOHMAN, D.J. \& SODHI, N.S. 2007 Cryptic species as a window on diversity and conservation. Trends in Ecology \& Evolution. 22:148-155.

BONEBRACKE, T.C., PONISIO, L.C., BOGGS, C.L. \& EHRLICH, P.R 2010. More than just indicators: a review of tropical butterfly ecology and conservation. Biol. Conserv. 143:1831-1841.

BOSSART, J.L. \& OPUNI-FRIMPONG, E. 2009. Distance from edge determines fruit-feeding butterfly community diversity in Afrotropical forest fragments. Environ. Entomol. 38(1):43-52.

BROWN JÚNIOR, K.S. 1992. Borboletas da Serra do Japi: diversidade, hábitats, recursos alimentares e variação temporal. In História Natural da Serra do Japi: Ecologia e preservação de uma área florestal no sudeste do Brasil (L.P.C. Morellato, ed.). Unicamp, São Paulo.
BROWN JÚNIOR, K.S. \& FREITAS, A.V.L. 1999. Lepidoptera. In Biodiversidade do Estado de São Paulo, Brasil. Invertebrados Terrestres (C.R.F. Brandão \& E.M. Cancello, eds.). FAPESP, São Paulo, p.225-245.

BROWN JÚNIOR, K.S. \& FREITAS, A.V.L. 2000. Diversidade de Lepidoptera em Santa Teresa, Espírito Santo. Bol. Mus. Biol. Mello Leitao. 11(12):71116.

BROWN JÚNIOR, K.S. 2005. Geological, evolutionary and ecological bases of the diversification of Neotropical butterflies: implications for conservation. In Tropical rainforests: Past, Present and Future (E. Bermingham., C.W. Dick \& C. Moritz, eds.). University of Chicago Press, Chicago, p. 166-201.

CABRAL, D.C. \& CESCO, S. 2008. Notas para uma história da exploração madeireira na Mata Atlântica do Sul-Sudeste. Ambient. Soc. 11(1):33-48.

CANALS, G.R. 2003. Mariposas de Misiones. L.O.L.A, Buenos Aires.

CARNEIRO, E., MIELKE, O.H.H., CASAGRANDE, M.M. 2008. Borboletas do sul da ilha de Santa Catarina, Florianópolis, Santa Catarina, Brasil (Lepidoptera: Hesperioidea e Papilionoidea). Shilap-Rev. Lepidopt. 36(142):261-271

CERQUEIRA, R., BRANT, A., NASCIMENTO, M.T. \& PARDINI, R. 2003. Fragmentação: alguns conceitos. In Fragmentação de Ecossistemas: Causas, efeitos sobre a biodiversidade e recomendações de políticas públicas. (D.M. Rambaldi \& D.A.S. Oliveira, eds.). MMA/SBF, Brasília, p.23-43.

CHAO, A., M.A, K.H. \& HSIEH, T.C. 2016. iNEXT Online: Interpolation and Extrapolation of species diversity. Institute of Statistics, National Tsing Hua University, Hsin-Chu, Taiwan. Disponível em: http://chao.stat.nthu.edu.tw/ wordpress/software_download/inext-online/ (accessed: 9 December 2018).

CLARKE, K.R. \& WARWICK, R.M. 1994. Change in Marine Communities. UK, National Research Concil. $144 \mathrm{p}$

COLPANI, I.M. \& SABEDOT-BORDIN, S.M. 2018. Borboletas frugívoras (Lepidoptera: Papilionoidea e Hesperioidea) em uma unidade de conservação e fragmentos florestais, no Sul do Brasil. Monografia, Universidade Comunitária da Região de Chapecó, Chapecó.

COLWEL, R.K. 2013. EstimateS: statistical estimation of species richness and shared species from samples. Version 9.1. User's guide and application. University of Connecticut, USA.

CONSERVAÇÃO INTERNACIONAL. 2013. Prioridade de Conservação. Hostspots. Disponível em: http://www.conservation.org.br/como/index. php?id=8 (accessed: 6 August 2018).

CORSO, G. \& HERNANDEZ, M.I.M. 2012. Borboletas frugívoras da Mata Atlântica no Parque Estadual da Serra do Tabuleiro, Santa Catarina, Brasil. Biotemas. 25(4):139-148.

D'ABRERA, B. 1988. Butterflies of the Neotropical region. Nymphalidae \& Satyridae. Victoria, Hill House.

DEVRIES, P. J. 1987. The butterflies of Costa Rica and their natural history. Papilionidae, Pieridae, Nymphalidae. Princeton University Press, New Jersey. 327p.

DICK, E.; DANIELI, M.A. \& ZANINI, A.M. 2013. Unidades de Conservação do oeste de Santa Catarina e a biodiversidade que protegem. In Biodiversidade catarinense: características, potencialidades e ameaças. (L. Sevegnani \& E. Schroeder, eds.). Edifurb, Blumenau, p.194-195.

DUARTE, M., MARCONATO, G., SPECHT, A., CASAGRANDE, M.M. 2012. Lepidoptera. In Insetos do Brasil: diversidade e taxonomia (J.A. Rafael, G.A.R, Melo,C.J.B. Carvalho, A.S. Casari \& R. Constantino, eds.). Holos, Ribeirão Preto, p.625-682.

FANTON, M., SABEDOT-BORDIN, S.M. 2014. Borboletas (Lepidoptera: Papilionoidea e Hesperioidea) do Parque Estadual Fritz Plaumann, Concórdia, SC. Trabalho de Conclusão de Curso, Universidade Comunitária da Região de Chapecó, Chapecó.

FATMA. Fundação do Meio Ambiente. 2016. Plano de Manejo do Parque Estadual das Araucárias. Florianópolis, Santa Catarina. 443p. 
FAVRETTO, M.A. 2012. Borboletas e Mariposas (Insecta: Lepidoptera) do Município de Joaçaba, Estado de Santa Catarina, Brasil. EntomoBrasilis. 5(2):167-169.

FAVRETTO, M.A., SANTOS, E.B., GEUSTER, C.J. 2013. Entomofauna do Oeste do Estado de Santa Catarina, Sul do Brasil. EntomoBrasilis. 6(1):42-63

FAVRETTO, M.A. \& SANTOS, E.B. 2014. Lepidoptera de uma área ribeirinha nos municípios de Ouro e Capinzal, Santa Catarina, Região Sul do Brasil, com um novo registro para o estado. REB. 7(1):35-42.

FAVRETTO, M.A., PIOVESAN, M., ORLANDIN, E. \& SANTOS, E.B. 2015. Lepidoptera em um fragmento urbano no sul do Brasil. Scientia Plena. 11(3):1-6.

FERRO, V.G., RESENDE, I.M.H. \& DUARTE, M. 2012. Mariposas Arctiinae (Lepidoptera: Erebidae) do estado de Santa Catarina, Brasil. Biota Neotrop. 12(4):1-15 http://www.biotaneotropica.org.br/v12n4/pt/ fullpaper?bn01312042012+en (accessed: 10 December 2018).

FREITAS, A.V.L. 2010. Impactos potenciais das mudanças propostas no Código Florestal Brasileiro sobre as borboletas.Biota Neotrop. 10(4):53-58 http:// www.biotaneotropica.org.br/v10n4/en/abstract?article+bn00810042010 (accessed: 9 December 2018).

FREITAS, A.V.L., EMERY, E.O. \& MILEKE, O.H.H. 2010. A new species of Moneuptychia Forster (Lepidoptera: Satyrinae: Euptychiina) from Central Brazil. Neotrop. Entomol. 39:83-90.

FREITAS, A.V.L. \& MARINI-FILHO, O.J. 2011. Plano de Ação Nacional para Conservação dos Lepidópteros Ameaçados de Extinção. Ministério do Meio Ambiente. Instituto Chico Mendes de Conservação da Biodiversidade, Brasília.

FREITAS, A.V.L., ALMEIDA, A.C. 2012. Lepidoptera: borboletas e mariposas do Brasil. São Paulo: Exclusiva Publicações, p.207.

FREITAS, A.V.L., ISERHARD, C.A., SANTOS, J.P., CARREIRA, J.Y.O., RIBEIRO, D.B., MELO, D.H.A., ROSA, A.H.B., MARINI-FILHO, O.J., ACCACIO, G.M. \& UEHARA-PRADO, M. 2014. Studies with butterfly bait traps: an overview. Rev. colomb. entomol. 40(2): 209-218.

GIOVENARDI, R., DI MARE, R.A., SPONCHIADO, J., ROANI, S.H., JACOMASSA, F.A.F., JUNG, A.B. \& PORN, M.A. 2008. Diversidade de Lepidoptera (Papilionoidea e Hesperioidea) em dois fragmentos de floresta no município de Frederico Westphalen, Rio Grande do Sul, Brasil. Rev. Bras. Entomol. 52(4):599-605.

GRACIOTIM, C. \& MORAIS, A.B.B. 2016. Borboletas frugívoras em florestas de Mata Atlântica do Parque Nacional do Iguaçu, Paraná, Brasil (Lepidoptera: Nymphalidae). Shilap-Rev. Lepidopt. 44(173):115-128.

HADDAD, N.M., BRUDVIG, L.A., CLOBERT, J., DAVIES, K.F., GONZALEZ, A., HOLT, R.D., LOVEJOY, T.E., SEXTON, J.O., AUSTIN, M.P., COLLINS, C.D., COOK, W.M., DAMSCHEN, E.I., EWERS, R.M., FOSTER, B.L., JENKINS, C.N., KING, A.J., LAURENCE, W.F., LEVEY, D.J., MARGULES, C.R., MELBOURNE, B.A., NICHOLLS, A.O., ORROCK, J.L., SONG, D.X. \& TOWSHEND, J.R. 2015. Habitat fragmentation and its lasting impacto on Earth's ecosystems. Science Advances. 1:1-9.

HAMMER , O. \& HARPER , D.A.T. 2009. Past: Paleontological Statistics. Version $2.17 \mathrm{c}$. Available at: $<$ http://folk.uio.no/ohammer/past $>$.

ICMBio. Instituto Chico Mendes de Conservação da Biodiversidade. 2013. Plano de Manejo da Floresta Nacional de Chapecó (Flona). Florianópolis, Santa Catarina. 147p.

KREMEN, C. 1992. Assessing the indicator properties of species assemblages for natural areas monitoring. Ecol. Appl. 2(2):203-217.

LAMAS, G. 2004. Checklist: Hesperioidea-Papilionoidea. In Atlas of Neotropical Lepidoptera. (J.B. Heppner, ed.). Association for Tropical Lepidoptera/Scientific Publishers, Gainesville, p.1-439.

LITTLEWOOD, N.A., STEWART, A.J.A. \& WOODCOCK, B.A. 2011. Science into practice how can fundamental science contribute to better management of grasslands for invertebrates? Insect Consect. Diver. 5: 1-8.
LUBENOW, A.M. 2016. Um alemão em Santa Catarina: A coleção entomológica Fritz Plaumann. Museologia e Interdisciplinaridade. 5(9):109-119.

MARÍN, L., LEÓN-CORTES, J.L. \& STEFANESCU, C. 2009. The effect of an agro-pasture landscape on diversity and migration patterns of frugivorous butterflies in Chiapas, Mexico. Biodiversity Conservation. 18: 919-934.

MYERS, N., MITTERMEIER, R.A., MITTERMEIER, C.G., FONSECA, G.A.B. \& KENT, J. 2000. Biodiversity hotspots for conservation priorities. Nature. 403:845-853.

MORAIS, A.B.B., ROMANOWSKI, H.P., ISERHARD, C.A., MARCHIORI, M.O.O. \& SEGUI, R. 2007. Mariposas del sur de Sudamérica (Lepidoptera: Hesperioidea y Papilionoidea). Ciencias Ambientales. 35(2): 29-46.

MORELLATO, L.P.C. \& HADDAD, C.F.B. 2000. Introduction: the Brazilian Atlantic Forest. Biotropica. 32:786-792.

NÚÑEZ-BUSTOS, E.O. 2010. Mariposas de la ciudad de Buenos Aires y alrededores. Vásquez Mazzini Editores, Buenos Aires. 264p.

ORLANDIN, E., FAVRETTO, M.A., PIOVESAN, M.S. \& BORTOLON, E. 2016. Borboletas e Mariposas de Santa Catarina: uma introdução. Campos Novos. 213p.

PEDROTTI, V.S., BARROS, M.P., ROMANOWSKI, H.P. \& ISERHARD, C. 2011. Borboletas frugívoras (Lepidoptera: Nymphalidae) ocorrentes em um fragmento de Floresta Ombrófila Mista no Rio Grande do Sul, Brasil. Biota Neotrop. 11(1): 385-390. http://www.biotaneotropica.org.br/v11n1/ pt/fullpaper?bn03011012011+pt (último acesso em 09/12/2018).

PEÑA, C. \& WAHLBERG, N. 2008. Prehistorical climate change increased diversification of a group of butterflies. Biol. Lett. 4: 274-278.

PIOVESAN, M., ORLANDIN, E., FAVRETTO, M.A. \& SANTOS, E.B. 2014. Contribuição para o conhecimento da lepidopterofauna de Santa Catarina, Brasil. Scientia Plena. 10(9):1-32.

RIBEIRO, M.C., METZGER, J.P., MARTENSEN, A.C., PONZONI, F.J. \& HIROTA, M.M. 2009. The Brazilian Atlantic Forest: How much is left, and how is the remaining forest distributed? Implications for conservation. Biol. Conserv. 142:1141-1153.

SAMWAYS, M. J. 2005. Insects Diversity conservation. Cambridge, University Press, 342p.

SANTOS, J.P., FREITAS, A.V.L., CONSTANTINO, P.A.L. \& UEHARAPRADO, M. 2014. Guia de identificação de tribos de borboletas frugívoras. Mata Atlântica - Norte. In Monitoramento de Biodiversidade. (A.B, Pereira \& P.A.L, Constantino, eds.). MMA/ICMBio/GIZ, Brasília. 12 p.

SCHMIDT, D.G., COSTA, L.C., ELPINO-CAMPOS, A. \& BARP, E.A. 2012. Diversidade de Borboletas (Lepidoptera) na Borda e no Interior de um Fragmento de Mata, no Município de Seara, Santa Catarina. Revista Saúde Meio Ambiente. 1(2): 1-15.

SERAPHIM, N., MAR IN, M.A., FREITAS, A.V.L., SILVA-BRANDÃO, K.L. 2014. Morphological and molecular marker contributions to disentangling the cryptic Hermeuptychia hermes species complex (Nymphalidae: Satyrinae: Euptychiina). Mol. Ecol. Resour. 14:39-49.

SIEWERT, R.R, SILVA, E.J.E. \& MIELKE. G.C. 2010a. Saturniidae from Santa Catarina state, Brazil, with taxonomi notes (Lepidoptera). Nachrichten des Entomologischen Vereins Apollo. 30(4):215-220.

SIEWERT, R.R. \& SILVA, E.J.E. 2010b. Contribution to the knowledge of the hawkmoths fauna in the state of Santa Catarina, Brazil (Lepidoptera: Sphingidae). Nachrichten des Entomologischen Vereins Apollo. 31(1/2):6366.

SILVA, A.R., TESTON, J.A. \& GARCIA, F.R.M. 2011. Borboletas. In Biodiversidade Floresta Nacional de Chapecó (F.R.M. Garcia, J.A. Lutinski \& C.J. Lutinski, eds.). Baraúna, São Paulo, p.117-178

SILVA, K.L.M.C. \& SABEDOT-BORDIN, S.M. 2015. Diversidade de borboletas (Insecta: Lepidoptera) em uma unidade de conservação no oeste de Santa Catarina. Monografia, Universidade Comunitária da Região de Chapecó, Chapecó. 
Bordin, S.M.S. et al.

TOTI, D.S., COYLE, F.A. \& MILLER, J.A. 2000. A structured inventory of Appalachian Grass Bald and Heath Bald spider assemblages and a test of species richness estimator performance. J. Arachnol. 28:329-345.

UEHARA-PRADO, M. 2003. Efeitos da fragmentação florestal na guilda de borboletas frugívoras do Planalto Atlântico Paulista. Dissertação de Mestrado, Universidade Estadual de Campinas, Campinas.

UEHARA-PRADO, M., BROWN JR., K.S. \& FREITAS, A.V.L. 2005. Biological traits of frugivorous butterflies in a fragmented and a continuous landscape in the south Brazilian Atlantic Forest. J. Lepid. Soc. 59(2):96-106.
VIBRANS, A.C., SEVEGNANI, L., GAPER, A.L. de., MULLER, J.J.V. \& REIS, M.S. 2013. Inventário Florístico Florestal de Santa Catarina. Blumenau: FURB. 3: 37p.

WAHLBERG, N., LENEVEU, J., KODANDARAMAIAH, U., PEÑA, C., NYLIN, S., FREITAS, A.V.L. \& BROWER, A.V.Z. 2009. Nymphalid butterflies diversity following near demise at the Cretaceous/Tertiary boundary. Proc. R. Soc. Lond. B. Biol. Sci. 276:4295-4302.

Received: $20 / 12 / 2018$

Revised: $22 / 06 / 2019$

Accepted: 01/08/2019

Published online:12/09/2019 